\title{
Increased glucagon-like peptide-1 secretion may be involved in antidiabetic effects of ginsenosides
}

\author{
Can Liu, Mian Zhang, Meng-yue Hu, Hai-fang Guo, Jia Li, Yun-li Yu, Shi Jin, \\ Xin-ting Wang, Li Liu and Xiao-dong Liu
}

Key Laboratory of Drug Metabolism and Pharmacokinetics, China Pharmaceutical University, Nanjing 210009, China
Correspondence should be addressed to L Liu; X-d Liu Emails liulee@yeah.net; xdliu@cpu.edu.cn

\begin{abstract}
Panax ginseng is one of the most popular herbal remedies. Ginsenosides, major bioactive constituents in $P$. ginseng, have shown good antidiabetic action, but the precise mechanism was not fully understood. Glucagon-like peptide-1 (GLP1) is considered to be an important incretin that can regulate glucose homeostasis in the gastrointestinal tract after meals. The aim of this study was to investigate whether ginseng total saponins (GTS) exerts its antidiabetic effects via modulating GLP1 release. Ginsenoside Rb1 (Rb1), the most abundant constituent in GTS, was selected to further explore the underlying mechanisms in cultured $\mathrm{NCl}-\mathrm{H} 716$ cells. Diabetic rats were developed by a combination of high-fat diet and low-dose streptozotocin injection. The diabetic rats orally received GTS (150 or $300 \mathrm{mg} / \mathrm{kg}$ ) daily for 4 weeks. It was found that GTS treatment significantly ameliorated hyperglycemia and dyslipidemia, accompanied by a significant increase in glucose-induced GLP1 secretion and upregulation of proglucagon gene expression. Data from $\mathrm{NCl}-\mathrm{H} 716$ cells showed that both GTS and Rb1 promoted GLP1 secretion. It was observed that Rb1 increased the ratio of intracellular ATP to ADP concentration and intracellular $\mathrm{Ca}^{2+}$ concentration. The metabolic inhibitor azide $(3 \mathrm{mM})$, the $\mathrm{K}_{\text {ATP }}$ channel opener diazoxide $(340 \mu \mathrm{M})$, and the $\mathrm{Ca}^{2+}$ channel blocker nifedipine $(20 \mu \mathrm{M})$ significantly reversed Rb1-mediated GLP1 secretion. All these results drew a conclusion that ginsenosides stimulated GLP1 secretion both in vivo and in vitro. The antidiabetic effects of ginsenosides may be a result of enhanced GLP1 secretion.
\end{abstract}

\section{Key Words}

- glucagon-like peptide-1 (GLP1)

- ginsenosides

- Rb1

- type 2 diabetes

- ginseng total saponins (GTS)

\section{Introduction}

Historical records on traditional medicinal systems reveal that Panax ginseng (P. ginseng, C A Meyer) has been used to treat diabetes for a long time (Xie et al. 2005c). Ginsenosides, major bioactive constituents in $P$. ginseng, are thought to be the main components responsible for the antidiabetic actions (Attele et al. 1999, 2002). Ginsenoside $\mathrm{Rb} 1$ ( $\mathrm{Rb} 1$ ) was also reported to be the most abundant constituent among more than 30 ginsenosides in ginseng root despite different sources and species (Washida \& Kitanaka 2003, Lim et al. 2005). A series of clinical trials and animal experiments have demonstrated that both $P$. ginseng and ginsenosides exerted insulinotropic effects and improved long-term glycemic control in type 2 diabetes (Kimura et al. 1981a,b, Yokozawa et al. 1985, Sotaniemi et al. 1995, Vuksan et al. 2000, Kim \& Park 2003, Yun et al. 2004, Ma et al. 2008, Vuksan et al. 2008,

Published by Bioscientifica Ltd 
Xiong et al. 2010). Several studies have been carried out to investigate the mechanisms of this glucose-lowering effect. Experiments using rats showed that Rb1 treatment reduces intracellular triglyceride accumulation in liver (Park et al. 2002). An in vitro study also demonstrated that Rb1 may suppress triglyceride accumulation in 3T3-L1 adipocytes and enhance insulin release in Min-6 cells via PKA pathways (Park et al. 2008b). It was also reported that $\mathrm{Rb} 1$ significantly stimulates basal and insulin-mediated glucose uptake in 3T3-L1 adipocytes and C2C12 myotubes via promoting GLUT1 and GLUT4 translocations to the cell surface (Shang et al. 2008). However, the real mechanisms of the antihyperglycemic effect have not been thoroughly elucidated due to poor absorption and low concentration of ginsenosides in plasma.

It is generally accepted that poor membrane permeability across the intestinal wall is the main factor limiting systemic exposure of most ginsenosides (Liu et al. 2009). Studies showed that $\mathrm{Rb} 1$ and $\mathrm{Rb} 2$ are poorly absorbed (Odani et al. 1983a,b), with bioavailabilities $<1 \%$. The peak concentrations of $\mathrm{Rb} 1$ and $\mathrm{Rb} 2$ following an oral dose $(50 \mathrm{mg} / \mathrm{kg})$ were only 5.51 and $0.35 \mu \mathrm{mol} / \mathrm{l}$ respectively. The findings show that poor absorption and low plasma concentration of ginsenosides after oral administration could not fully characterize its glucose-lowering potency. In fact, this pharmacokineticpharmacological paradox is not special to ginsenosides but is common in many natural compounds.

However, it is noteworthy that local high concentration of ginsenosides in intestine may interact with intestinal epithelium, where numerous endocrine cells are located. Glucagon-like peptide-1 (GLP1), secreted by enteroendocrine L-cells, is one of the most important incretins in the regulation of glucose homeostasis and insulin secretion (Baggio \& Drucker 2007, Ranganath 2008). Our recent studies revealed that, berberine, another poorly absorbed natural product, may reduce blood glucose levels partly via stimulating GLP1 release (Lu et al. 2009, Yu et al. 2010). This indicated that, similar to berberine, ginsenosides may exert antidiabetic activity via stimulating GLP1 secretion.

The aim of this study was to investigate whether ginseng total saponins (GTS) treatment could enhance GLP1 secretion and ameliorate glucose and lipid homeostasis in type 2 diabetic rats induced by a combination of high-fat diet and low-dose streptozotocin (STZ). The effects and mechanisms of GTS and Rb1 on GLP1 secretion were also investigated in cultured NCI-H716 cells, a widely used human enteroendocrine L-cell line.

\section{Materials and methods}

\section{Materials}

GTS (ginsenosides content $>80 \%$ ) from one batch and purified ginsenosides Rb1, Rb2, Rc, Rd, Re, Rg1, Rf, and $\operatorname{Rg} 2$ (purity >99\%) were purchased from Jilin University (Changchun, China). Pentobarbital, digoxin, STZ, ADP, and ATP were obtained from Sigma-Aldrich. Primary anti-insulin antibody was purchased from Abcam Co. (Cambridge, MA, USA). Rabbit anti-GLP1 antibody was bought from Phoenix Pharmaceuticals (Burlingame, CA, USA).

\section{Analysis of ginsenosides by LC-MS}

To investigate the chemical composition of GTS, a validated LC-MS method was employed to analyze the contents of eight major ginsenosides namely $\mathrm{Rb} 1, \mathrm{Rb} 2, \mathrm{Rc}$, Rd, Re, Rf, Rg1, and Rg2 (Xie et al. 2005a). Briefly, stock solutions were prepared at $2 \mathrm{mg} / \mathrm{ml}$ in DMSO and diluted with 95\% methanol before experiments. Chromatographic separation was performed using a Waters Symmetry $\mathrm{C}_{18}$ column $(5.0 \mu \mathrm{m}, 2.1 \times 150 \mathrm{~mm})$. The mobile phase was composed of a mixture of $\mathrm{NH}_{4} \mathrm{Cl}(0.15 \mathrm{mM})$ in water i) and acetonitrile ii) at a flow rate of $0.2 \mathrm{ml} / \mathrm{min}$. The gradient conditions were as follows: $0-3 \mathrm{~min}$ at $25 \% \mathrm{~B}$, $3-10 \mathrm{~min}$ at $25-60 \% \mathrm{~B}, 10-18 \mathrm{~min}$ at $60-90 \% \mathrm{~B}$, $18-20 \mathrm{~min}$ at $90-25 \% \mathrm{~B}$, and $20-25 \mathrm{~min}$ at $25 \% \mathrm{~B}$. Analysis in the mass spectrometer with ESI probe was operated in the selected ion monitoring model: $m / z[\mathrm{M}+\mathrm{Cl}]^{2-} 589.25$ for $\mathrm{Rb} 1,[\mathrm{M}+\mathrm{Cl}]^{-} 1113.5$ for $\mathrm{Rb} 2$ and $\mathrm{Rc},[\mathrm{M}+\mathrm{Cl}]^{-} 981.45$ for Rd and Re, $[\mathrm{M}+\mathrm{Cl}]^{-} 835.4$ for $\mathrm{Rg} 1$ and Rf, $[\mathrm{M}+\mathrm{Cl}]^{-} 819.4$ for $\mathrm{Rg} 2$, and $[\mathrm{M}+\mathrm{Cl}]^{-} 815.35$ for digoxin (internal standard).

The contents $(\mathrm{w} / \mathrm{w})$ in GTS of the ginsenosides Rb1, $\mathrm{Rb} 2, \mathrm{Rc}, \mathrm{Rd}$, Re, Rf, Rg1, and Rg2 were measured to be 21 , $18,16,9,11,1,5$, and $3 \%$ respectively. The result showed that content of eight ginsenosides was $84 \%$ and ginsenoside Rb1 was the most abundant constituent in GTS.

\section{Animals}

Male Sprague Dawley rats (weighing 100-120 g), purchased from Sino-British Sipper \& BK Lab Animal Ltd. (Shanghai, China), were housed in a controlled environment of temperature $\left(23 \pm 1^{\circ} \mathrm{C}\right)$ and relative humidity $(50 \pm 5 \%)$ with $12 \mathrm{~h}$ light: $12 \mathrm{~h}$ darkness cycle. Water and food were allowed ad libitum. All animal experimental procedures were approved by the Animal Ethics Committee of China Pharmaceutical University.

Published by Bioscientifica Ltd 


\section{Induction of experimental diabetes in rats and GTS treatment}

Experimental type 2 diabetic rats were induced by combination of high-fat diet and low-dose STZ injection according to a method described previously (Reed et al. 2000, Chen et al. 2011). Following an acclimation period of 3 days, the rats were assigned randomly to three groups: control (CON) group, high-fat diet-fed (HFD) group, and diabetic (DM) group. The CON rats were fed on normal chow while both HFD rats and DM rats were fed on highfat diet, which contains $15 \% \mathrm{w} / \mathrm{w}$ lard, $5 \% \mathrm{w} / \mathrm{w}$ sesame oil, $20 \% \mathrm{w} / \mathrm{w}$ sucrose, $2.5 \% \mathrm{w} / \mathrm{w}$ cholesterol, and $57.5 \% \mathrm{w} / \mathrm{w}$ normal chow. After 4 weeks of dietary manipulation, the rats were fasted overnight. DM rats received an i.p. injection of STZ $(35 \mathrm{mg} / \mathrm{kg}$, dissolved in citrate buffer at $\mathrm{pH} 4.5$ ). Both HFD and CON rats received an equivalent volume of citrate buffer. On day 7 post-STZ injection, only rats with fasting blood glucose (FBG) levels higher than $11.1 \mathrm{mM}$ were selected as diabetic rats for further studies.

Diabetic rats were divided into three groups randomly: diabetic control (DM) group, low-dose treatment group(DM$\mathrm{GL}$ ), and high-dose treatment group (DM-GH), which received oral daily dose of vehicle, $150 \mathrm{mg} / \mathrm{kg}$ GTS, or $300 \mathrm{mg} / \mathrm{kg}$ GTS for 4 weeks respectively.

\section{Oral glucose tolerance test}

On day 21 of the treatment, an oral glucose tolerance test (OGTT) was performed. Rats were fasted for $6 \mathrm{~h}$ followed by an oral dose of glucose $(2 \mathrm{~g} / \mathrm{kg})$. Plasma glucose and insulin levels were determined at 0 (baseline), 15, 30, 60, and $120 \mathrm{~min}$ after glucose administration.

\section{Sample collection and GLP1 assessment}

On day 28 of the treatment, rats were fasted for $6 \mathrm{~h}$. At $2 \mathrm{~h}$ after last treatment, portal vein catheter implantation was performed under pentobarbital anesthesia $(60 \mathrm{mg} / \mathrm{kg}$, i.p.). Serial blood samples (about $300 \mu \mathrm{l}$ ) were collected in Eppendorf tubes containing EDTA and dipeptidyl peptidase-IV (DPP-IV) inhibitor $(10 \mu \mathrm{l} / \mathrm{ml}$, Linco Research, St Charles, MO, USA) via the catheter before and at 10, 20, and $30 \mathrm{~min}$ following glucose loading $(2.5 \mathrm{~g} / \mathrm{kg}$ via gavage). Blood samples were centrifuged at $1500 \boldsymbol{g}$ for $10 \mathrm{~min}$ and stored at $-80^{\circ} \mathrm{C}$ for assessing insulin and GLP1 concentration.

Then the rats were killed immediately. The pancreas, segments of distal ileum, and proximal colon were rapidly harvested and stored at $-80{ }^{\circ} \mathrm{C}$ until processed. Parts of ileum and colon were used for immunohistochemistry and quantitative RT-PCR analysis, and the rest were used for GLP1 assessment.

GLP1 levels were measured using a GLP1(7-36) amide active ELISA kit (Linco Research). Plasma insulin was measured by iodine $\left[{ }^{125} \mathrm{I}\right]$ insulin RIA kit (BNIBT Co., Beijing, China). Homeostatic model assessment (HOMA) was used to assess the longitudinal changes in insulin resistance (HOMA-IR).

\section{Measurement of $\mathbf{R b} 1$ concentration in intestine}

Normal male Sprague Dawley rats (280-300 g) received an oral dose of GTS (300 mg/kg). Rats were killed and intestinal contents and mucosa in segments of distal ileum and proximal colon were harvested at 2 and $4 \mathrm{~h}$ following GTS administration. Contents and mucosa were homogenized in PBS and ginsenosides were extracted by n-butanol saturated with water. Ginsenoside Rb1 concentration in plasma, intestinal contents, and mucosa were measured by LC-MS.

\section{Immunohistochemistry}

$\beta$-Cell mass in pancreas as well as L-cell number in ileum were measured using immunohistochemistry carried out as described previously (Lu et al. 2009, Yu et al. 2009, 2010). For ileum tissue, results are expressed as the number of L-cells per mucosal area (number $/ \mathrm{mm}^{2}$ ). For pancreas, $\beta$-cell volume density was estimated by calculating the proportion of cells immunoreactive for insulin per sectional area of total pancreas. The $\beta$-cell mass was calculated by multiplying the $\beta$-cell volume density by the weight of the pancreas.

\section{Cell culture and GLP1 secretion studies}

Human NCI-H716 cells were obtained from the American Type Culture Collection (Manassas, VA, USA). Cells were maintained in suspension in RPMI-1640 at $37^{\circ} \mathrm{C}$ under $5 \% \mathrm{CO}_{2}$. Two days before the experiments, cell adhesion and endocrine differentiation were initiated by growing cells $\left(1.5 \times 10^{6} /\right.$ well $)$ in dishes coated with Matrigel (Becton Dickinson Co., Bedford, MA, USA) in high-glucose DMEM. On the day of the experiment, supernatants were replaced by Krebs-Ringer bicarbonate (KRB) buffer (128.8 mM NaCl, $4.8 \mathrm{mM} \mathrm{KCl,} 1.2 \mathrm{mM} \mathrm{KH}_{2} \mathrm{PO}_{4}$, $1.2 \mathrm{mM} \mathrm{MgSO}_{4}, 2.5 \mathrm{mM} \mathrm{CaCl}_{2}, 5 \mathrm{mM} \mathrm{NaHCO}$, and $10 \mathrm{mM}$ HEPES, pH 7.4) containing $0.2 \% \mathrm{w} / \mathrm{v}$ BSA with or without test agents. After incubation at $37^{\circ} \mathrm{C}$ for $2 \mathrm{~h}$, the supernatant was collected with the addition of $50 \mu \mathrm{g} / \mathrm{ml}$

Published by Bioscientifica Ltd 
phenylmethylsulphonyl fluoride for GLP1 analysis. No damage on cells was found for all the agents within tested concentrations.

\section{Measurement of intracellular ATP and ADP}

The intracellular ATP and ADP levels were determined by the HPLC method described previously with minor modifications (Volonté et al. 2004, Varum et al. 2011). In brief, differentiated cells $\left(1.5 \times 10^{6} /\right.$ well $)$ were incubated with KRB buffer containing $0.2 \%$ BSA with or without $\mathrm{Rb} 1$ for 0.5 or $1 \mathrm{~h}$. Then cells were scraped off and sonicated. ATP and ADP were extracted with 5\% w/v 5-sulfosalicylic acid followed by centrifugation. Supernatants were neutralized with $2 \mathrm{M} \mathrm{NaOH}$. All steps were carried out on ice. Separation was achieved using a Waters Symmetry $\mathrm{C}_{18}$ column $(5.0 \mu \mathrm{m}, 4.6 \times 150 \mathrm{~mm})$. The mobile phase (adjusted $\mathrm{pH}$ to 6.5 ) was $8 \% \mathrm{v} / \mathrm{v}$ methanol containing $70 \mathrm{mM} \mathrm{NaH} \mathrm{PO}_{4}$, and $3 \mathrm{mM}$ tetrabutyl ammonium bromide at a flow rate of $1 \mathrm{ml} / \mathrm{min}$. The u.v.-VIS 20A detector (Shimadzu, Kyoto, Japan) was set a wavelength at $220 \mathrm{~nm}$. Results are given as the ratio of 2 (ATP:ADP ratio).

\section{Measurement of intracellular $\mathrm{Ca}^{2+}$ level}

NCI-H716 cells were grown and differentiated on Matrigelcoated glass-bottomed dishes. Before starting the experiment, cells were washed with KRB buffer three times and loaded with the $\mathrm{Ca}^{2+}$ indicator Fluo-3 AM $(5 \mu \mathrm{mol} / \mathrm{l}$, Beyotime Biotechnology, Jiangsu, China) in the dark for $45 \mathrm{~min}$ at $37^{\circ} \mathrm{C}$. Then cells were washed three times with KRB buffer. At the beginning of the experiment, the mean baseline fluorescence was acquired, followed by the stimulation of tested agents. $\mathrm{Ca}^{2+}$ transient was recorded by a laser scanning confocal microscope (TCS SP5, Leica, Germany) with Leica application suite (Advanced Fluorescence 2.2.0). Fluorescence was monitored at the emission wavelength of $525 \mathrm{~nm}$, with the excitation wavelength at $488 \mathrm{~nm}$ (Reimer et al. 2001, Li et al. 2012a,b, Lupescu et al. 2012).

\section{Quantitative RT-PCR}

Quantitative RT-PCR was used to measure $G c g$ mRNA (for proglucagon gene) and Pcsk1 mRNA (for prohormone convertase 3 (Pc3) gene) in rat ileum (on day 28) or human NCI-H716 cells (incubated with Rb1 for $24 \mathrm{~h}$ ). Briefly, total RNA from frozen tissue or cells was isolated using TRIzol reagent (SunShine Biotechnology, Nanjing, China) according to the manufacturer's instruction. The quality and purity of RNA were determined by u.v. spectrophotometry at 260 and $280 \mathrm{~nm}$. Quantitative RT-PCR was performed with an input of cDNA converted from $2 \mu \mathrm{g}$ of total RNA. Primer sequences of rat mRNA: forward 5'-ACACGGAGGA GAACGCCAGA-3', reverse 5'-GCGGGAGTCCAGGTA TTTGC-3' for proglucagon gene; forward 5'-CTTCT TTTCTCTCAGCCCTTCCTAC-3', reverse 5'-CATTCATTGA CAAACTGCCTCTTC-3' for $P c 3$ gene; and forward 5'-GGGAAATCGTGCGTGACATT-3', reverse 5'-GCGGCA GTGGCCATCTC- $3^{\prime}$ for $\beta$-actin gene. Primer sequences of human mRNA: forward 5'-TGTCAGCGTAATATCTGTGA GGC-3', reverse 5'-AGCAGGTGAAGAGAGAGCAAGC-3' for proglucagon gene; forward 5'-CAGAAGGCTTTTGAATA TGGTGT-3', reverse 5'-GGAGGCACTGCTGATGGAGAT- $3^{\prime}$ for $P c 3$ gene; and forward $5^{\prime}$-CAGTCGGTTGGAGCGAGCA T-3', reverse $5^{\prime}$-GGACTTCCTGTAACAACGCATCT-3' for $\beta$-actin gene.

After denaturing at $95^{\circ} \mathrm{C}$ for $2 \mathrm{~min}$, the amplification was obtained by 40 cycles of $95^{\circ} \mathrm{C}$ for $5 \mathrm{~s}$ and $60^{\circ} \mathrm{C}$ for $30 \mathrm{~s}$. Melting curves were performed to investigate the specificity of the PCR reaction. Relative quantification of each gene expression was calculated according to a comparative $C t$ method using the formula: $R Q=2^{-\Delta C t}$.

\section{Statistical analysis}

Results were expressed as mean \pm s.E.m. Statistical differences among groups were evaluated by one-way ANOVA. Differences between groups were estimated using Student-Newman-Keuls multiple comparison post hoc test when necessary. A $P$ value of $<0.05$ indicated a significant difference.

\section{Result}

\section{Features of DM rats and HFD rats}

Physiological and biochemical parameters were measured in CON rats, HFD rats, DM rats, and DM rats treated with GTS (Table 1 and Fig. 1). In response to STZ injection, levels of glucose, triglyceride (TG), total cholesterol (TC), and free fatty acids (FFA) in plasma of DM rats were significantly higher than those in CON rats, accompanied by reductions in body weight gain. DM rats also developed diabetic symptoms such as polyphagia, polyuria, and polydipsia. High levels of insulin as well as HOMA-IR were observed in DM rats (Table 1). As shown in Fig. 1C, the OGTT results also showed that DM rats had significantly higher postprandial glucose concentrations induced by glucose loading ( $2 \mathrm{~g} / \mathrm{kg}$, post ovulation (p.o.)), leading to significant increase in area under concentration-

Published by Bioscientifica Ltd 
Table 1 Alterations in body weight, parameters of glucose, and lipid metabolism in diabetic rats after 4 weeks of GTS treatment. DM-GL rats and DM-GH rats were treated with GTS 150 and $300 \mathrm{mg} / \mathrm{kg}$ per day for 4 weeks respectively. Data shown are mean \pm s.E.M. ( $n=5$ )

\section{Parameter}

Body weight $(g)$

Liver weight ( $\%$ of body weight)

TG $(\mathrm{mmol} / \mathrm{l})$

$\mathrm{TC}(\mathrm{mmol} / \mathrm{l})$

FFA ( $g / l)$

FBG $(\mathrm{mmol} / \mathrm{l})$

Fasted insulin level (mIU/l)

HOMA-IR

\begin{tabular}{r}
\hline CON \\
\hline $420.2 \pm 10.7$ \\
$3.38 \pm 0.07$ \\
$1.73 \pm 0.19$ \\
$1.74 \pm 0.05$ \\
$0.49 \pm 0.09$ \\
$7.63 \pm 1.16$ \\
$24.78 \pm 3.34$ \\
$7.89 \pm 0.30$
\end{tabular}

\begin{tabular}{c}
\hline DM \\
\hline $301.5 \pm 7.9^{\dagger}$ \\
$4.8 \pm 0.13^{\dagger}$ \\
$10.81 \pm 2.21^{\dagger}$ \\
$27.98 \pm 3.42^{\dagger}$ \\
$1.45 \pm 0.25^{\star}$ \\
$23.19 \pm 1.24^{\dagger}$ \\
$30.46 \pm 5.30$ \\
$30.5 \pm 4.29^{\dagger}$
\end{tabular}

\begin{tabular}{r}
\hline DM-GL \\
\hline $304.1 \pm 14.6^{\dagger}$ \\
$4.75 \pm 0.16^{\dagger}$ \\
$8.28 \pm 1.92^{*}$ \\
$21.56 \pm 3.94^{\dagger}$ \\
$1.65 \pm 0.52$ \\
$19.12 \pm 2.09^{\dagger}$ \\
$26.58 \pm 2.52$ \\
$22.74 \pm 3.75^{\dagger}$
\end{tabular}

\begin{tabular}{c}
\hline DM-GH \\
\hline $299.4 \pm 13.1^{\dagger}$ \\
$4.71 \pm 0.15^{\dagger}$ \\
$4.91 \pm 0.52^{+, \neq}$ \\
$21.88 \pm 2.42^{\dagger}$ \\
$0.83 \pm 0.21$ \\
$19.31 \pm 0.81^{+, \neq}$ \\
$28.99 \pm 2.55$ \\
$24.82 \pm 2.34^{\dagger}$
\end{tabular}

${ }^{*} P<0.05,{ }^{\dagger} P<0.01$ vs CON rats and ${ }^{\ddagger} P<0.05$, vs DM rats.

time curve (AUC) values of glucose. These indexes were similar to the physiopathological state of type 2 diabetes, indicating that the DM rats may be considered as type 2 diabetic rats (Reed et al. 2000, Srinivasan et al. 2005). HFD rats showed both higher plasma insulin concentrations and HOMA-IR index, inferring the development of IR (Table 1).

\section{Plasma glucose, insulin, and lipid levels}

Four-week GTS treatment significantly decreased energy intake (Fig. 1A) and normalized TG, TC, and FFA levels
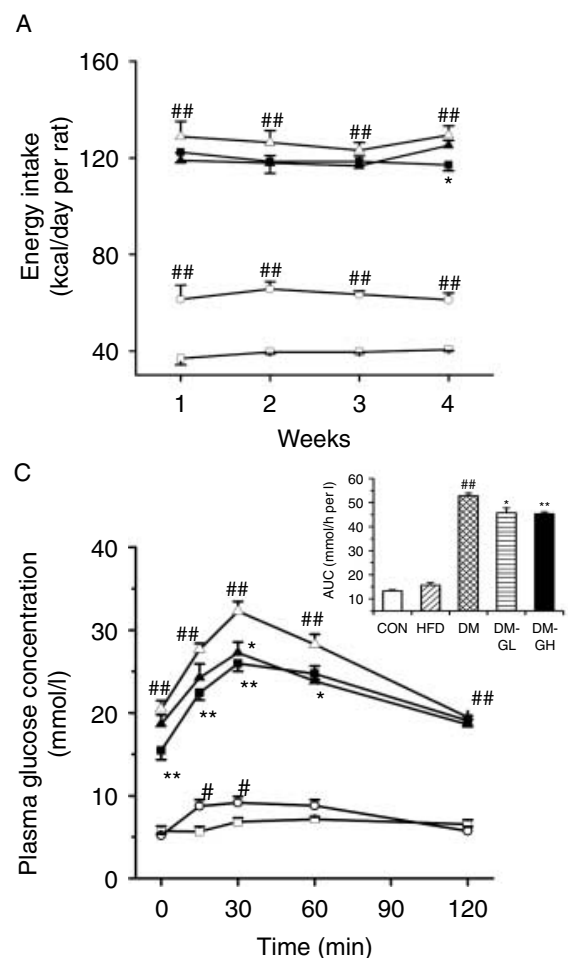

Figure 1

Effects of GTS on energy intake (A) and fasted plasma glucose (B) in DM rats during 4 weeks of treatment; postprandial plasma glucose (C) and insulin levels (D) on OGTT on day 21. DM-GL rats and DM-GH rats were treated with GTS 150 and $300 \mathrm{mg} / \mathrm{kg}$ per day for 4 weeks respectively. Symbols represent but failed to influence body weight and liver weight (Table 1). Further study showed that GTS treatment dramatically decreased FBG levels especially in the last 2 weeks (Fig. 1B and Table 1). Although fasting insulin level remained unchanged, the rats treated with GTS showed lower HOMA-IR index compared with DM rats (Table 1). Data from the OGTT conducted on day 21 showed that GTS treatment significantly reduced postprandial blood glucose levels induced by glucose loading ( $2 \mathrm{~g} / \mathrm{kg}$, p.o.; Fig. 1C), resulting in lower AUC of glucose
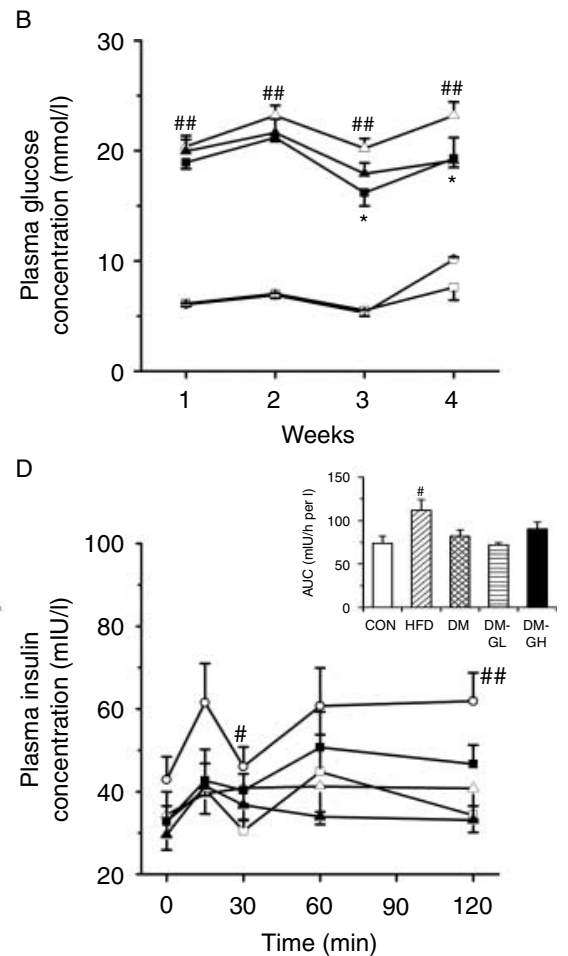

as follows: open square, CON rats; open circle, HFD rats; open triangle, DM rats; filled triangle, DM-GL rats; and filled square, DM-GH rats. Values are expressed as mean \pm S.E.M. $(n=5),{ }^{\#} P<0.05,{ }^{\# \#} P<0.01$ vs CON rats and ${ }^{*} P<0.05, * * P<0.01$ vs DM rats.

Published by Bioscientifica Ltd. 
(Fig. 1C inset) compared with those in DM rats. Moreover, higher doses of GTS treatment stimulated an increment in insulin levels (Fig. 1D) induced by glucose loading. However, the increment did not reach statistical significance. All these results further verified the antidiabetic effect of GTS.

On day 28, glucose levels and insulin levels in plasma of portal vein were also monitored together with GLP1 following glucose loading $(2.5 \mathrm{~g} / \mathrm{kg}$, p.o.). It was apparent that compared with DM rats, GTS treatment remarkably decreased plasma glucose concentrations (Fig. 2A), which was in line with the results of the OGTT (Fig. 1C). GTS treatment also displayed a trend to increase insulin level induced by glucose loading, with a significant increase in DM-GH rats (Fig. 2B).

Measurement of pancreas insulin levels was also performed at $30 \mathrm{~min}$ after glucose loading on day 28 (Fig. 2C). High doses of GTS treatment increased pancreas insulin levels when compared with control rats, although no significance was found. The $\beta$-cell volume density corresponds to the ratio of insulin immunoreactivity area to pancreatic parenchymal area. The $\beta$-cell mass was
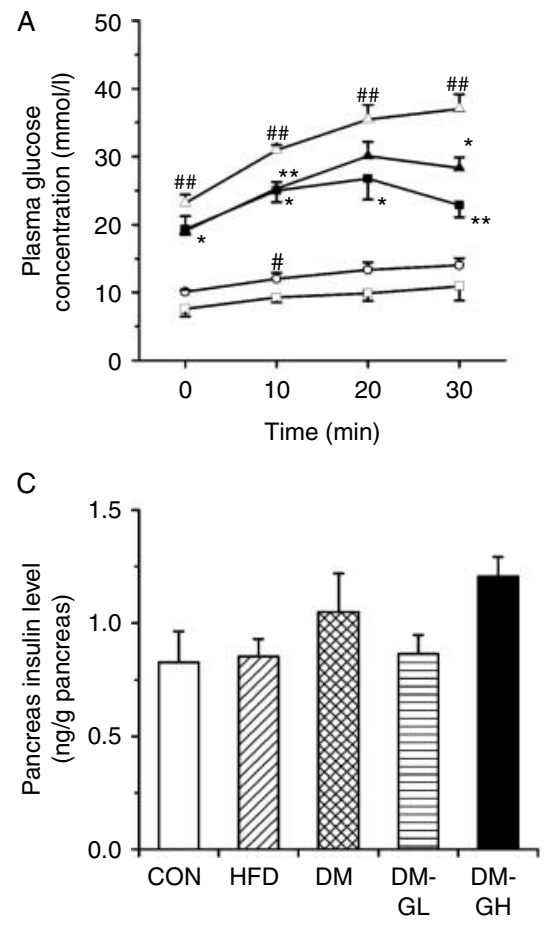

Figure 2

Effects of 4-week GTS treatment on glucose (A) and insulin levels (B) in portal vein, pancreas insulin level (C), and $\beta$-cell mass (D) in DM rats. DM-GL rats and DM-GH rats were treated with GTS 150 and $300 \mathrm{mg} / \mathrm{kg}$ per day for 4 weeks respectively. Plasma samples were collected before and at 10, 20, and $30 \mathrm{~min}$ following glucose loading $(2.5 \mathrm{~g} / \mathrm{kg}$, p.o.) on day 28 . Pancreas samples were obtained at $30 \mathrm{~min}$ after glucose loading. $\beta$-Cell proliferation calculated by multiplying the $\beta$-cell volume density by the weight of the pancreas (Yu et al. 2010). The data from immunohistochemistry showed that high-dose GTS treatment significantly increased $\beta$-cell mass by 2.52 -fold compared with DM rats (Fig. 2D).

\section{GLP1 secretion in rats}

Assessment of GLP1 levels in portal plasma was conducted after glucose loading (2.5 g/kg, p.o.) on day 28 (Fig. 3A) and AUC from 0 to 30 min $\left(\mathrm{AUC}_{0-30}\right)$ was estimated using the linear trapezoidal rule. The results confirmed that DM rats exhibited greater basal GLP1 levels than CON rats, which was consistent with those previously reported (Cani et al. 2005). Obviously, glucose loading induced GLP1 release in all experimental rats. Compared with DM rats, high-dose GTS treatment did not produce appreciable effects on basal GLP1 levels but enhanced glucose-induced GLP1 release, which continued rising to the peak at $20 \mathrm{~min}$ $(96.4 \pm 7.85 \mathrm{pM}$ in DM-GH rats vs $57.1 \pm 11.5 \mathrm{pM}$ in DM rats, $P<0.05$ ) and stayed high to the end of the experiment. A similar increase was obtained in DM-GL group, although
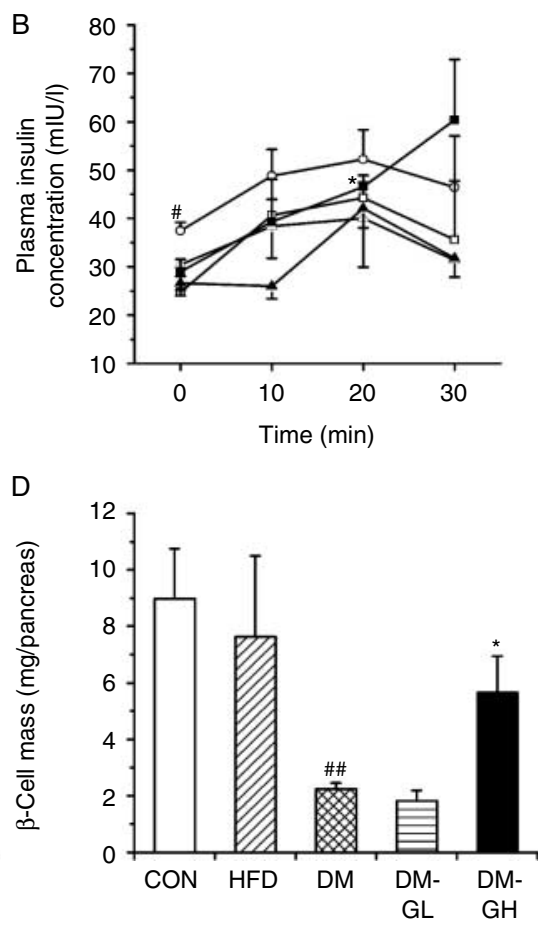

was presented by $\beta$-cell mass, detected by immunohistochemistry. Symbols represent as follows: open square, CON rats; open circle, HFD rats; open triangle, DM rats; filled triangle, DM-GL rats; and filled square, DM-GH rats. Values are expressed as means \pm s.E.M. $(n=5),{ }^{\#} P<0.05,{ }^{\# \#} P<0.01$ vs CON rats and $* P<0.05, * * P<0.01$ vs DM rats.

Published by Bioscientifica Ltd. 
A
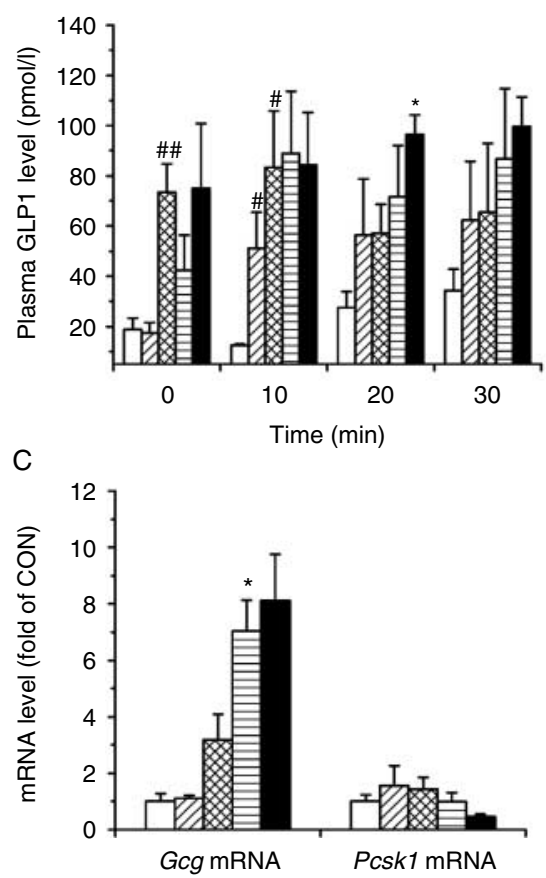

Figure 3

Effects of 4-week GTS treatment on GLP1 secretion. (A) Portal vein GLP1 level, (B) GLP1 content in intestinal tract, (C) Gcg mRNA (for proglucagon gene) and Pcsk1 mRNA (for Pc3 gene) expression in ileum, and (D) intestinal L-cell number. DM-GL rats and DM-GH rats were treated with GTS 150 and $300 \mathrm{mg} / \mathrm{kg}$ per day for 4 weeks respectively. Plasma samples were collected before and at 10, 20, and $30 \mathrm{~min}$ following glucose loading ( $2.5 \mathrm{~g} / \mathrm{kg}$, p.o.)

no significance was found. Meanwhile, GTS treatment also increased the $\mathrm{AUC}_{0-30}$ of GLP1 $(44.69 \pm 6.50 \mathrm{pmol} / \mathrm{h}$ per 1 in DM-GH rats vs $34.97 \pm 6.94 \mathrm{pmol} / \mathrm{h}$ per 1 in $\mathrm{DM}$ rats). These results indicated that GTS treatment enhanced GLP1 secretion induced by glucose loading.

GLP1 levels in ileum and colon was measured at $30 \mathrm{~min}$ after glucose loading (Fig. 3B). High-dose GTS treatment significantly increased GLP1 concentrations in the ileum. However, the enhancement did not occur in the colon.

The proglucagon gene is the precursor gene of GLP1. GLP1(7-36) amide is produced by a tissue-specific posttranslational process of proglucagon peptide by PC3 (Rouillé et al. 1995). Levels of $G c g$ mRNA (for proglucagon gene) and Pcsk1 mRNA (for Pc3 gene) in ileum segments were assessed. The results showed that diabetes upregulated expression of $G c g$ mRNA. GTS treatment further increased $G c g$ mRNA expression (Fig. 3C). By contrast, GTS treatment did not elicit a marked alteration in Pcsk1 mRNA expression.

The L-cells were identified in the microvilli of the intestinal lumen by immunohistochemistry. Compared with DM rats, high-dose GTS treatment significantly
B
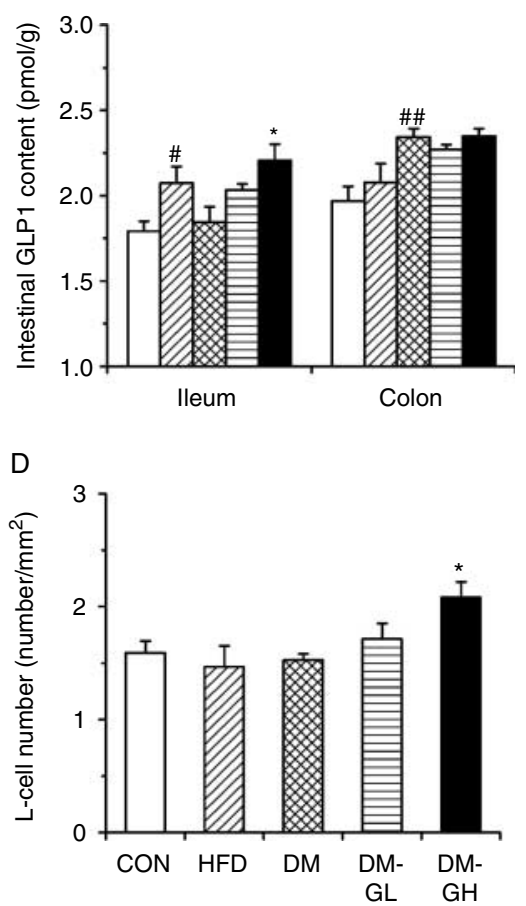

on day 28. GLP1 content in ileum and colon were obtained at $30 \mathrm{~min}$ after glucose loading. Positive L-cells were identified using immunohistochemistry. Symbols represent as follows: open bar, CON rats; diagonally striped bar, HFD rats; cross-hatched bar, DM rats; horizontally striped bar, DM-GL rats; and black bar, DM-GH rats. Values are expressed as mean \pm s.E.M. $(n=5)$, ${ }^{\#} P<0.05,{ }^{\# \#} P<0.01$ vs CON rats and ${ }^{\star} P<0.05$ vs DM rats.

increased the number of GLP1-positive L-cells in the ileum (Fig. 3D). Besides, no obvious alteration was observed in DM rats compared with CON rats.

\section{Rb1 level in intestine after oral GTS administration}

Rb1 level in plasma, intestinal contents, and mucosa were investigated at 2 and $4 \mathrm{~h}$ following GTS administration (300 mg/kg, p.o.). The results showed that $\mathrm{Rb} 1$ in plasma was only $204.9 \pm 47.5 \mathrm{ng} / \mathrm{ml}$ at $2 \mathrm{~h}$ and $225.1 \pm 15.8 \mathrm{ng} / \mathrm{ml}$ at $4 \mathrm{~h}$ following GTS administration. At $2 \mathrm{~h}$, the $\mathrm{Rb} 1$ concentration in ileal mucosa was $873.3 \pm 80.5 \mu \mathrm{g} / \mathrm{g}$ mucosa while a higher Rb1 concentration appeared in ileal contents $(4.27 \pm 0.81 \mathrm{mg} / \mathrm{g}$ content). At $4 \mathrm{~h}$, the $\mathrm{Rb} 1$ concentration in ileal mucosa and in contents was $298.1 \pm 36.5 \mu \mathrm{g} / \mathrm{g}$ mucosa and $728.1 \pm 284.4 \mu \mathrm{g} / \mathrm{g}$ content respectively. For colon, the $\mathrm{Rb} 1$ concentration in mucosa and contents was only $14.1 \pm 9.9 \mu \mathrm{g} / \mathrm{g}$ mucosa and $48.2 \pm 13.3 \mu \mathrm{g} / \mathrm{g}$ content at $2 \mathrm{~h}$ and then increased to $118.8 \pm 19.8 \mu \mathrm{g} / \mathrm{g}$ mucosa and $2.34 \pm 0.68 \mathrm{mg} / \mathrm{g}$ content at $4 \mathrm{~h}$ respectively.

Published by Bioscientifica Ltd 


\section{GLP1 secretion in NCl-H716 cells}

$\mathrm{Rb} 1, \mathrm{Rb} 2, \mathrm{Rc}, \mathrm{Rd}$, and Re were found to be major ginsenosides in GTS. The effects of the five major ginsenosides on GLP1 secretion were investigated in the NCI-H716 cell line. The results showed that tested agents $(100 \mu \mathrm{M})$ possessed similar efficacy enhancing GLP1 secretion except Re (Fig. 4A). Extent of increase in GLP1 release induced by GTS ( 100 and $200 \mu \mathrm{g} / \mathrm{ml}$ ) was similar to that by $\mathrm{Rb} 1$. This study showed that Rb1 was the most abundant constituent in GTS; therefore, Rb1 was selected to be the representative constituent for further studies.

The following study showed that ginsenoside Rb1 dose dependently stimulated GLP1 secretion (Fig. 4A). GLP1 secretion from the cells was glucose dependent (Fig. 4B). $\mathrm{Rb} 1(100 \mu \mathrm{M})$ increased GLP1 secretion by 1.56 -fold at $5.5 \mathrm{mM}$ glucose concentration compared with 1.41 -fold without glucose, whereas $\mathrm{Rb} 1$ did not produce further increments at $11.1 \mathrm{mM}$ glucose concentration.

\section{GCG mRNA and PCSK1 mRNA expression in $\mathrm{NCl}-\mathrm{H} 716$ cells}

As mentioned earlier, both GCG mRNA and PCSK1 mRNA were related to GLP1 production. Data from quantitative RT-PCR analysis showed that Rb1 treatment significantly increased GCG mRNA as well as PCSK1 mRNA expression compared with control cells, which indicated that $\mathrm{Rb} 1$ may affect GLP1 biosynthesis (Fig. 4C).

\section{Cellular energy metabolism, intracellular $\mathrm{Ca}^{2+}$ level, and $\mathrm{K}_{\text {ATP }}$ channel in $\mathrm{NCl}-\mathrm{H716}$ cells}

Some reports showed that GLP1 release is involved in cellular energy metabolism and intracellular $\mathrm{Ca}^{2+}$ levels. The intracellular levels of ATP and ADP were assessed, and the ratio of ATP and ADP levels (ATP:ADP) was calculated. Consistent with our expectation, ginsenoside Rb1 significantly elevated the ATP:ADP ratio (Fig. 5A). The metabolic inhibitor azide ( $3 \mathrm{mM}$ ) may reverse the increase in GLP1 secretion induced by Rb1 (Fig. 5C).

In addition, $\mathrm{Rb} 1$ remarkably increased intracellular $\mathrm{Ca}^{2+}$ levels while this augmentation is slow and reversible. (Fig. 5B). Furthermore, the presence of $20 \mu \mathrm{M}$ nifedipine, an L-type $\mathrm{Ca}^{2+}$ channel blocker, abrogated the Rb1induced increase in GLP1 secretion (Fig. 5C). Substitution of extracellular medium by $\mathrm{Ca}^{2+}$-free KRB buffer also abolished the stimulation of GLP1 secretion induced by Rb1. Similarly, adding $340 \mu \mathrm{M}$ diazoxide, a $\mathrm{K}_{\mathrm{ATP}}$ channel opener, also attenuated the rise of GLP1 secretion induced
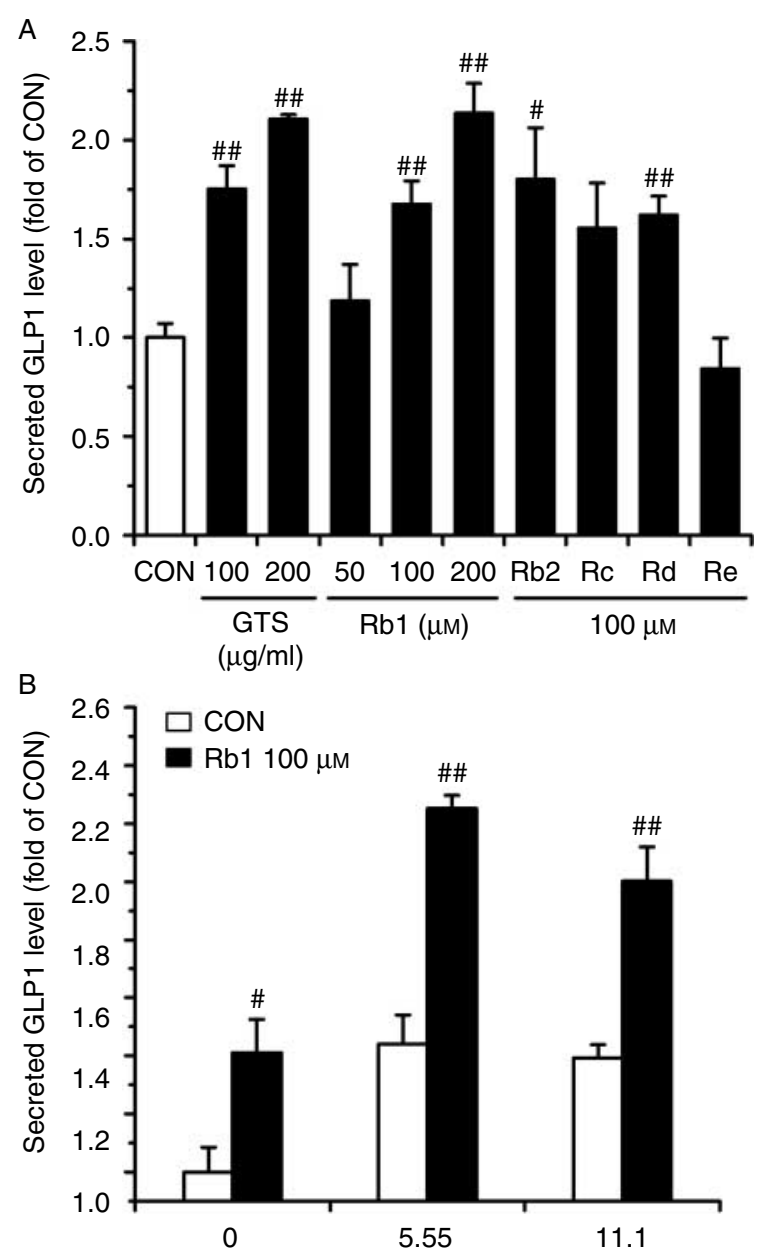

Glucose concentration $(\mu \mathrm{M})$

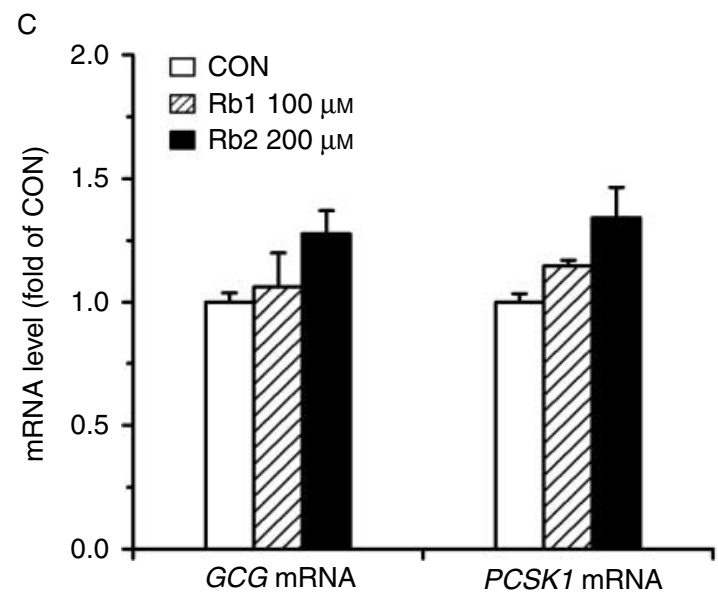

Figure 4

Effects of GTS and ginsenosides (Rb1, Rb2, Rc, Rd, and Re) on GLP1 secretion in $\mathrm{NCl}-\mathrm{H} 716$ cells (A). Effects of Rb1 incubation with glucose on GLP1 secretion (B). GCG mRNA and PCSK1 mRNA gene expression in $\mathrm{NCl}-\mathrm{H} 716$ cells $(\mathrm{C})$. Values are expressed as mean \pm s.E.M. $(n=5-8),{ }^{\#} P<0.05$ and ${ }^{\# \#} P<0.01$ vs CON. 

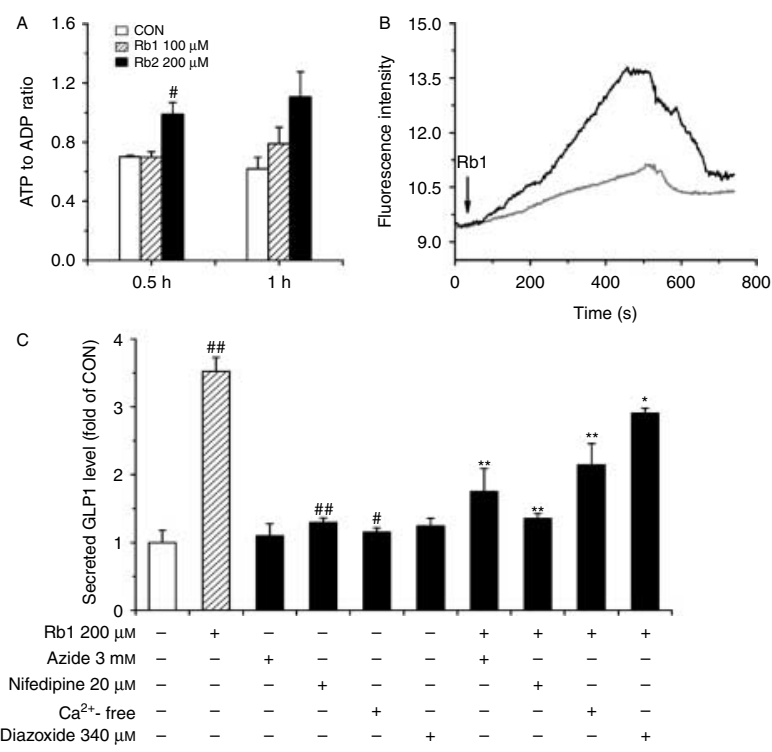

\section{Figure 5}

Effects of Rb1 on cellular energy metabolism (ATP:ADP ratio; $A$ ) and cytosolic $\mathrm{Ca}^{2+}$ transient in $\mathrm{NCl}-\mathrm{H} 716$ cells induced by ginsenoside $\mathrm{Rb} 1$ $100 \mu \mathrm{M}$ (gray line) and $200 \mu \mathrm{M}$ (black line; B). Effects of azide (3 mM), nifedipine $(20 \mu \mathrm{M})$, diazoxide $(340 \mu \mathrm{M})$, and $\mathrm{Ca}^{2+}$-free $\mathrm{KRB}$ buffer on GLP1 secretion induced by Rb1 $(200 \mu \mathrm{M})$ in NCl-H716 cells (C). Values are expressed as mean \pm s.E.M. $(n=5-8),{ }^{\#} P<0.05,{ }^{\# \#} P<0.01$ vs $C O N$ and $* P<0.05, * * P<0.01$ vs $\mathrm{Rb} 1$.

by Rb1 (Fig. 5C). All these results indicated that GLP1 release stimulated by $\mathrm{Rb} 1$ may be involved in cellular energy metabolism, intracellular $\mathrm{Ca}^{2+}$ level, and $\mathrm{K}_{\mathrm{ATP}}$ channel.

\section{Discussion}

As they account for over $60 \%$ of postprandial insulin release, incretin hormones have become a promising treatment for controlling type 2 diabetes, especially when traditional hypoglycemic agents appear to be ineffective (Salehi et al. 2010). Based on incretin hormones, current drug development focuses on GLP1 analogs as well as DPP-IV inhibitors (Reimann 2010). However, these newly approved chemicals have displayed some untoward reactions (Elashoff et al. 2011, Knezevich et al. 2012). One alternative approach is to seek some natural compounds that may stimulate intestinal L-cells and trigger endogenous GLP1 release. The major finding of this study was that ginsenosides may be a potent stimulator of GLP1 secretion.

According to our results, GTS treatment may lower both FBG and postprandial plasma glucose, accompanied by an increase in insulin levels in plasma and pancreatic tissue, as well as $\beta$-cell mass. GTS treatment may partly improve lipid homeostasis and reduce HOMA-IR index. All these results verified the therapeutic value of GTS with regard to type 2 diabetes.

As we expected, $300 \mathrm{mg} / \mathrm{kg}$ GTS treatment significantly increased GLP1 release induced by glucose loading ( $2.5 \mathrm{~g} / \mathrm{kg}$, p.o.). Peripherally released GLP1 may access the brain and participate in the regulation of anorexic response (Lu et al. 2009), which indicated that suppression of food intake induced by GTS may partly be due to enhancement of GLP1 release. It was well known that GLP1 exerts important effects on regulating glucose homeostasis via stimulating insulin secretion, stimulating $\beta$-cell proliferation, inhibiting food intake, etc. (Holst 2007), which was observed in this study. It was noticed that GTS promoted proglucagon gene expression and L-cell proliferation in the intestine of diabetic rats. These findings implied that enhancement of GLP1 release may be partially attributed to promoted GLP1 biosynthesis and L-cell function.

Our results indicated that a high concentration of Rb1 existed in distal intestine, which may directly interact with intestinal epithelial endocrine L-cells. As mentioned earlier, ginsenosides are poorly absorbed while high concentrations of ginsenosides in the intestine may be responsible for GLP1 secretion. Compared with the ileum, the $\mathrm{Rb} 1$ concentration in the colon contents was very low at $2 \mathrm{~h}$, which indicated that GTS did not reach the colon at that time. This fact also explained that GTS treatment did not influence GLP1 levels in the colon (Fig. 3B).

NCI-H716 cells served as an in vitro model of the intestinal L-cell to further investigate the effect of GTS on regulating GLP1 release. In vitro study demonstrated that GTS may provoke an increase in GLP1 secretion from the NCI-H716 cells, in accordance with in vivo findings. We further evaluated the effects of five major ginsenosides in GTS. All the tested ginsenosides enhanced GLP1 secretion except Re, which indicated that ginsenosides were the major compounds stimulating GLP1 secretion. Rb1, the most abundant constituent in GTS, served as the representative constituent for further experiments. Rb1 stimulated GLP1 secretion in a dose-dependent manner and exhibited a synergistic effect with glucose in GLP1 secretion. GCG and PCSK1 mRNA expression were also promoted in NCI-H716 cells treated with Rb1.

GLP1 secretion induced by glucose was under modulation of many factors including cellular energy metabolism, closure of $\mathrm{K}_{\mathrm{ATP}}$ channels (Reimann \& Gribble 2002), electrogenic coupled $\mathrm{Na}^{+}$and glucose entry via sodium-coupled glucose co-transporters (Gribble et al. 2003),

Published by Bioscientifica Lto. 
sweet taste receptors, and G-protein-coupled receptor pathways (Jang et al. 2007, Chu et al. 2008). Some studies have demonstrated that ginseng may enhance glucosestimulated insulin secretion via increasing ATP levels, affecting activity of $\mathrm{K}_{\mathrm{ATP}}$ channels and $\mathrm{Ca}^{2+}$ channels (Luo \& Luo 2006, Park et al. 2008a). We discovered that Rb1 significantly increased the ATP:ADP ratio and cytosolic $\mathrm{Ca}^{2+}$ levels in NCI-H716 cells. Further study proved that the enhancement of GLP1 secretion induced by Rb1 was partly diminished by the presence of azide, diazoxide, and nifedipine. These results implied that an elevated ATP:ADP ratio stimulated by $\mathrm{Rb} 1$ could result in the closure of $\mathrm{K}_{\mathrm{ATP}}$ channels and membrane depolarization and in turn trigger the opening of voltage-gated calcium channels. Then elevation in the cytosolic free $\mathrm{Ca}^{2+}$ concentration triggers the exocytotic response of GLP1. Besides, as ginsenosides are amphipathic, the possibility that $\mathrm{Rb} 1$ increased cytosolic $\mathrm{Ca}^{2+}$ acting as a detergent could not be ruled out.

It is of interest that hyperglycemia was effectively attenuated by GTS treatment while insulin level was only marginally increased (Fig. 1C and D). Similarly, $\beta$-cell mass markedly increased in the DM-GH group while pancreatic insulin content just increased moderately compared with DM rats (Fig. 2C and D). These phenomena may be attributed to the ameliorated IR. Similar reports showed that plasma glucose level and plasma insulin level may decrease simultaneously when the diabetic conditions are improved efficiently (Attele et al. 2002, Xie et al. 2005b, Yoon et al. 2007, Xiong et al. 2010, Yang et al. 2010). In our experiment, increased GLP1 secretion induced by ginsenosides may mediate these effects. It is well known that GLP1 exhibits potent insulinotropic and glucose-lowering actions. In addition, chronic GLP1 enhancement may strongly inhibit glucagon secretion, reduce food intake, slow gastric emptying, exert insulin-like effects, and increase insulin sensitivity and $\beta$-cell function (Young et al. 1999, Holst 2007). These factors may result in a great amelioration in IR. For instance, GLP1 increases glycogen synthesis and glucose transport in skeletal muscles and liver (Redondo et al. 2003, Acitores et al. 2004). The existence of GLP1 can also amplify insulin signaling in adipocytes (Gao et al. 2007). Moreover, lipid homeostasis improved by GTS treatment (Table 1) and augmented GLP1 release may further ameliorate IR. Meanwhile, we cannot exclude the possible role of absorbed ginsenosides on IR and glucose homeostasis. In our experiment, although the absolute amount of insulin did not increase, poor potency of insulin was attenuated after the treatment. Improved insulin sensitivity may require less insulin to maintain glucose disposal (Xiong et al. 2010). Thus, it is reasonable to consider that GLP1 as well as $\beta$-cell mass markedly increased in the DM-GH group while insulin content in plasma and pancreas just increased moderately. In addition, enhanced insulin level may have appeared obviously due to the insulinotropic action of GLP1 as well as ginsenosides (Kimura et al. 1981b, Rotshteyn \& Zito 2004, Park et al. 2008b) during the treatment.

In conclusion, this study suggested that modulating GLP1 secretion as well as relative gene expression may be one of the mechanisms by which ginsenosides exert their antidiabetic effect. The underlying molecular mechanism involved elevation of the ATP:ADP ratio, subsequent $\mathrm{K}_{\text {ATP }}$ channel closure, and the opening of $\mathrm{Ca}^{2+}$ channels. These findings may suggest that it is endogenous GLP1 that acts as a critical mediator of this antidiabetic action, which shed some light on the pharmacokinetic-pharmacological paradox of ginsenosides.

\section{Declaration of interest}

The authors declare that there is no conflict of interest that could be perceived as prejudicing the impartiality of the research reported.

\section{Funding}

This work has received grants from National Youth Science Foundation of China (no. 81102503), Fundamental Research Funds for the Central Universities (no. JKY2011018), and National Science Foundation of China (no. 81273587).

\section{References}

Acitores A, González N, Sancho V, Valverde I \& Villanueva-Peñacarrillo ML 2004 Cell signalling of glucagon-like peptide-1 action in rat skeletal muscle. Journal of Endocrinology 180 389-398. (doi:10.1677/joe.0. 1800389)

Attele AS, Wu JA \& Yuan CS 1999 Ginseng pharmacology: multiple constituents and multiple actions. Biochemical Pharmacology 58 1685-1693. (doi:10.1016/S0006-2952(99)00212-9)

Attele AS, Zhou YP, Xie JT, Wu JA, Zhang L, Dey L, Pugh W, Rue PA, Polonsky KS \& Yuan CS 2002 Antidiabetic effects of Panax ginseng berry extract and the identification of an effective component. Diabetes 51 1851-1858. (doi:10.2337/diabetes.51.6.1851)

Baggio LL \& Drucker DJ 2007 Biology of incretins: GLP-1 and GIP. Gastroenterology 132 2131-2157. (doi:10.1053/j.gastro.2007.03.054)

Cani PD, Daubioul CA, Reusens B, Remacle C, Catillon G \& Delzenne NM 2005 Involvement of endogenous glucagon-like peptide-1(7-36) amide on glycaemia-lowering effect of oligofructose in streptozotocin-treated rats. Journal of Endocrinology 185 457-465. (doi:10.1677/joe.1.06100)

Chen GM, Hu N, Liu L, Xie SS, Wang P, Li J, Xie L, Wang GJ \& Liu XD 2011 Pharmacokinetics of verapamil in diabetic rats induced by combination of high-fat diet and streptozotocin injection. Xenobiotica 41 494-500. (doi:10.3109/00498254.2011.558933)

Chu ZL, Carroll C, Alfonso J, Gutierrez V, He H, Lucman A, Pedraza M, Mondala H, Gao H, Bagnol D et al. 2008 A role for intestinal endocrine cell-expressed G protein-coupled receptor 119 in glycemic control by

Published by Bioscientifica Ltd. 
enhancing glucagon-like peptide-1 and glucose-dependent insulinotropic peptide release. Endocrinology 149 2038-2047. (doi:10.1210/ en.2007-0966)

Elashoff M, Matveyenko AV, Gier B, Elashoff R \& Butler PC 2011 Pancreatitis, pancreatic, and thyroid cancer with glucagon-like peptide-1-based therapies. Gastroenterology 141 150-156. (doi:10.1053/ j.gastro.2011.02.018)

Gao H, Wang X, Zhang Z, Yang Y, Yang J, Li X \& Ning G 2007 GLP-1 amplifies insulin signaling by up-regulation of IR $\beta$, IRS- 1 and Glut4 in 3T3-L1 adipocytes. Endocrine 32 90-95. (doi:10.1007/ s12020-007-9011-4)

Gribble FM, Williams L, Simpson AK \& Reimann F 2003 A novel glucosesensing mechanism contributing to glucagon-like peptide-1 secretion from the GLUTag cell line. Diabetes 52 1147-1154. (doi:10.2337/ diabetes.52.5.1147)

Holst JJ 2007 The physiology of glucagon-like peptide 1. Physiological Reviews 87 1409-1439. (doi:10.1152/physrev.00034.2006)

Jang HJ, Kokrashvili Z, Theodorakis MJ, Carlson OD, Kim BJ, Zhou J, Kim HH, Xu X, Chan SL, Juhaszova M et al. 2007 Gut-expressed $\alpha$-gustducin and taste receptors regulate secretion of glucagon-like peptide-1. PNAS 104 15069-15074. (doi:10.1073/pnas.0706890104)

Kim SH \& Park KS 2003 Effects of Panax ginseng extract on lipid metabolism in humans. Pharmacological Research 48 511-513. (doi:10.1016/S10436618(03)00189-0)

Kimura M, Waki I, Chujo T, Kikuchi T, Hiyama C, Yamazaki K \& Tanaka O $1981 a$ Effects of hypoglycemic components in ginseng radix on blood insulin level in alloxan diabetic mice and on insulin release from perfused rat pancreas. Journal of Pharmacobio-Dynamics 4 410-417. (doi:10.1248/bpb1978.4.410)

Kimura M, Waki I, Tanaka O, Nagai Y \& Shibata S 1981b Pharmacological sequential trials for the fractionation of components with hypoglycemic activity in alloxan diabetic mice from ginseng radix. Journal of Pharmacobio-Dynamics 4 402-409. (doi:10.1248/bpb1978.4.402)

Knezevich E, Crnic T, Kershaw S \& Drincic A 2012 Liraglutide-associated acute pancreatitis. American Journal of Health-System Pharmacy 69 386-389. (doi:10.2146/ajhp110221)

Li J, Wang P, Yu S, Zheng Z \& Xu X 2012a Calcium entry mediates hyperglycemia-induced apoptosis through $\mathrm{Ca}^{2+} /$ calmodulin-dependent kinase II in retinal capillary endothelial cells. Molecular Vision $\mathbf{1 8}$ 2371-2379.

Li X, Chen Z, Jiang Z, Li Y \& Zhang Y 2012b Zinc reverses glycinedependent inactivation of NMDARs in cultured rat hippocampal neurons. Science China. Life sciences 55 1075-1081. (doi:10.1007/ s11427-012-4421-9)

Lim W, Mudge KW \& Vermeylen F 2005 Effects of population, age, and cultivation methods on ginsenoside content of wild American ginseng (Panax quinquefolium). Journal of Agricultural and Food Chemistry $\mathbf{5 3}$ 8498-8505. (doi:10.1021/jf051070y)

Liu H, Yang J, u F, Gao X, Ma X, Huang Y, Xu F, Niu W, Wang F, Mao Y et al. 2009 Absorption and disposition of ginsenosides after oral administration of Panax notoginseng extract to rats. Drug Metabolism and Disposition 37 2290-2298. (doi:10.1124/dmd.109.029819)

Lu SS, Yu YL, Zhu HJ, Liu XD, Liu L, Liu YW, Wang P, Xie L \& Wang GJ 2009 Berberine promotes glucagon-like peptide-1 (7-36) amide secretion in streptozotocin-induced diabetic rats. Journal of Endocrinology $\mathbf{2 0 0}$ 159-165. (doi:10.1677/JOE-08-0419)

Luo JZ \& Luo L 2006 American ginseng stimulates insulin production and prevents apoptosis through regulation of uncoupling protein- 2 in cultured $\beta$-cells. Evidence-Based Complementary and Alternative Medicine 3 365-372. (doi:10.1093/ecam/nel026)

Lupescu A, Jilani K, Zbidah M, Lang E \& Lang F 2012 Enhanced Ca ${ }^{2+}$ entry, ceramide formation, and apoptotic death of erythrocytes triggered by plumbagin. Journal of Natural Products 75 1956-1961. (doi:10.1021/ np300611r)

Ma SW, Benzie IF, Chu TT, Fok BS, Tomlinson B \& Critchley LA 2008 Effect of Panax ginseng supplementation on biomarkers of glucose tolerance, antioxidant status and oxidative stress in type 2 diabetic subjects: results of a placebo-controlled human intervention trial. Diabetes, Obesity \& Metabolism 10 1125-1127. (doi:10.1111/j.1463-1326.2008. 00858.x)

Odani T, Tanizawa H \& Takino Y 1983a Studies on the absorption, distribution, excretion and metabolism of ginseng saponins. II. The absorption, distribution and excretion of ginsenoside $\operatorname{Rg} 1$ in the rat. Chemical \& Pharmaceutical Bulletin 31 292-298. (doi:10.1248/ cpb.31.292)

Odani T, Tanizawa H \& Takino Y 1983b Studies on the absorption, distribution, excretion and metabolism of ginseng saponins. III. The absorption, distribution and excretion of ginsenoside $\mathrm{Rb} 1$ in the rat. Chemical \& Pharmaceutical Bulletin 31 1059-1066. (doi:10.1248/ cpb.31.1059)

Park KH, Shin HJ, Song YB, Hyun HC, Cho HJ, Ham HS, Yoo YB, Ko YC, Jun WT \& Park HJ 2002 Possible role of ginsenoside Rb1 on regulation of rat liver triglycerides. Biological \& Pharmaceutical Bulletin 25 457-460. (doi:10.1248/bpb.25.457)

Park MW, Ha J \& Chung SH 2008a 20(S)-ginsenoside Rg3 enhances glucose-stimulated insulin secretion and activates AMPK. Biological \& Pharmaceutical Bulletin 31 748-751. (doi:10.1248/bpb.31.748)

Park S, Ahn IS, Kwon DY, Ko BS \& Jun WK 2008b Ginsenosides Rb1 and Rg1 suppress triglyceride accumulation in 3T3-L1 adipocytes and enhance $\beta$-cell insulin secretion and viability in Min6 cells via PKA-dependent pathways. Bioscience, Biotechnology, and Biochemistry 72 2815-2823. (doi:10.1271/bbb.80205)

Ranganath LR 2008 Incretins: pathophysiological and therapeutic implications of glucose-dependent insulinotropic polypeptide and glucagon-like peptide-1. Journal of Clinical Pathology 61 401-409. (doi:10.1136/jcp.2006.043232)

Redondo A, Trigo MV, Acitores A, Valverde I \& Villanueva-Peñacarrillo ML 2003 Cell signalling of the GLP-1 action in rat liver. Molecular and Cellular Endocrinology 204 43-50. (doi:10.1016/S0303-7207(03)00146-1)

Reed MJ, Meszaros K, Entes LJ, Claypool MD, Pinkett JG, Gadbois TM \& Reaven GM 2000 A new rat model of type 2 diabetes: the fat-fed, streptozotocin-treated rat. Metabolism 49 1390-1394. (doi:10.1053/ meta.2000.17721)

Reimann F 2010 Molecular mechanisms underlying nutrient detection by incretin-secreting cells. International Dairy Journal 20 236-242. (doi:10.1016/j.idairyj.2009.11.014)

Reimann F \& Gribble FM 2002 Glucose-sensing in glucagon-like peptide-1-secreting cells. Diabetes 51 2757-2763. (doi:10.2337/ diabetes.51.9.2757)

Reimer RA, Darimont C, Gremlich S, Nicolas-Métral V, Rüegg UT \& Macé K 2001 A human cellular model for studying the regulation of glucagonlike peptide-1 secretion. Endocrinology 142 4522-4528. (doi:10.1210/ en.142.10.4522)

Rotshteyn Y \& Zito SW 2004 Application of modified in vitro screening procedure for identifying herbals possessing sulfonylurea-like activity. Journal of Ethnopharmacology 93 337-344. (doi:10.1016/ j.jep.2004.04.007)

Rouillé Y, Martin S \& Steiner DF 1995 Differential processing of proglucagon by the subtillisin-like prohormone convertase PC2 and PC3 to generate either glucagon or glucagon-like peptide. Journal of Biological Chemistry 270 26488-26496. (doi:10.1074/jbc.270.44.26488)

Salehi M, Aulinger B, Prigeon RL \& D'Alessio DA 2010 Effect of endogenous GLP-1 on insulin secretion in type 2 diabetes. Diabetes 59 1330-1337. (doi:10.2337/db09-1253)

Shang W, Yang Y, Zhou L, Jiang B, Jin H \& Chen M 2008 Ginsenoside Rb1 stimulates glucose uptake through insulin-like signaling pathway in 3T3-L1 adipocytes. Journal of Endocrinology 198 561-569. (doi:10.1677/ JOE-08-0104)

Sotaniemi EA, Haapakoski E \& Rautio A 1995 Ginseng therapy in noninsulin-dependent diabetic patients. Diabetes Care 18 1373-1375. (doi:10.2337/diacare.18.10.1373) 
Srinivasan K, Viswanad B, Asrat L, Kaul CL \& Ramarao P 2005 Combination of high-fat diet-fed and low-dose streptozotocin-treated rat: a model for type 2 diabetes and pharmacological screening. Pharmacological Research 52 313-320. (doi:10.1016/j.phrs.2005.05.004)

Varum S, Rodrigues AS, Moura MB, Momcilovic O, Easley CA, Ramalho-Santos J, Van Houten B \& Schatten G 2011 Energy metabolism in human pluripotent stem cells and their differentiated counterparts. PLoS ONE 6 e20914. (doi:10.1371/journal.pone.0020914)

Volonté MG, Yuln G, Quiroga P \& Consolini AE 2004 Development of an HPLC method for determination of metabolic compounds in myocardial tissue. Journal of Pharmaceutical and Biomedical Analysis 35 647-653. (doi:10.1016/j.jpba.2004.02.002)

Vuksan V, Sievenpiper JL, Koo VY, Francis T, Beljan-Zdravkovic U, Xu Z \& Vidgen E 2000 American ginseng (Panax quinquefolius L) reduces postprandial glycemia in nondiabetic subjects and subjects with type 2 diabetes mellitus. Archives of Internal Medicine 160 1009-1013. (doi:10.1001/archinte.160.7.1009)

Vuksan V, Sung MK, Sievenpiper JL, Stavro PM, Jenkins AL, Di Buono M, Lee KS, Leiter LA, Nam KY, Arnason JT et al. 2008 Korean red ginseng (Panax ginseng) improves glucose and insulin regulation in well-controlled, type 2 diabetes: results of a randomized, double-blind, placebo-controlled study of efficacy and safety. Nutrition, Metabolism, and Cardiovascular Diseases 18 46-56. (doi:10.1016/j.numecd. 2006.04.003)

Washida D \& Kitanaka S 2003 Determination of polyacetylenes and ginsenosides in Panax species using high performance liquid chromatography. Chemical \& Pharmaceutical Bulletin 51 1314-1317. (doi:10.1248/cpb.51.1314)

Xie HT, Wang GJ, Sun JG, Tucker I, Zhao XC, Xie YY, Li H, Jiang XL, Wang R, Xu MJ et al. 2005a High performance liquid chromatographic-mass spectrometric determination of ginsenoside $\mathrm{Rg} 3$ and its metabolites in rat plasma using solid-phase extraction for pharmacokinetic studies. Journal of Chromatography. B, Analytical Technologies in the Biomedical and Life Sciences 818 167-173. (doi:10.1016/j.jchromb. 2004.12.028)

Xie JT, Mehendale SR, Li X, Quigg R, Wang X, Wang CZ, Wu JA, Aung HH, A Rue P, Bell GI et al. 2005b Anti-diabetic effect of ginsenoside Re in ob/ob mice. Biochimica et Biophysica Acta 1740 319-325. (doi:10.1016/ j.bbadis.2004.10.010)

Xie JT, Mehendale S \& Yuan CS $2005 c$ Ginseng and diabetes. American Journal of Chinese Medicine 33 397-404. (doi:10.1142/ S0192415X05003004)

Xiong Y, Shen L, Liu KJ, Tso P, Wang G, Woods SC \& Liu M 2010 Antiobesity and antihyperglycemic effects of ginsenoside Rb1 in rats. Diabetes 59 2505-2512. (doi:10.2337/db10-0315)

Yang CY, Wang J, Zhao Y, Shen L, Jiang X, Xie ZG, Liang N, Zhang L \& Chen ZH 2010 Anti-diabetic effects of Panax notoginseng saponins and its major anti-hyperglycemic components. Journal of Ethnopharmacology 130 231-236. (doi:10.1016/j.jep.2010.04.039)

Yokozawa T, Kobayashi T, Oura H \& Kawashima Y 1985 Studies on the mechanism of the hypoglycemic activity of ginsenoside-Rb2 in streptozotocin-diabetic rats. Chemical \& Pharmaceutical Bulletin 33 869-872. (doi:10.1248/cpb.33.869)

Yoon SH, Han EJ, Sung JH \& Chung SH 2007 Anti-diabetic effects of compound $\mathrm{K}$ versus metformin versus compound K-metformin combination therapy in diabetic $d b / d b$ mice. Biological \& Pharmaceutical Bulletin 30 2196-2200. (doi:10.1248/bpb.30.2196)

Young AA, Gedulin BR, Bhavsar S, Bodkin N, Jodka C, Hansen B \& Denaro M 1999 Glucose-lowering and insulin-sensitizing actions of exendin-4: studies in obese diabetic $(o b / o b, d b / d b)$ mice, diabetic fatty Zucker rats, and diabetic rhesus monkeys (Macaca mulatta). Diabetes 48 1026-1034. (doi:10.2337/diabetes.48.5.1026)

Yu YL, Lu SS, Yu S, Liu YC, Wang P, Xie L, Wang GJ \& Liu XD 2009 Huang-lian-jie-du-decoction modulates glucagon-like peptide-1 secretion in diabetic rats. Journal of Ethnopharmacology 124 444-449. (doi:10.1016/j.jep.2009.05.027)

Yu YL, Liu L, Wang XT, Liu X, Liu X, Xie L \& Wang G 2010 Modulation of glucagon-like peptide-1 release by berberine: in vivo and in vitro studies. Biochemical Pharmacology 79 1000-1006. (doi:10.1016/ j.bcp.2009.11.017)

Yun SN, Moon SJ, Ko SK, Im BO \& Chung SH 2004 Wild ginseng prevents the onset of high-fat diet induced hyperglycemia and obesity in ICR mice. Archives of Pharmacal Research 27 790-796. (doi:10.1007/ BF02980150)

Received in final form 2 February 2013

Accepted 26 February 2013

Accepted Preprint published online 26 February 2013
(C) 2013 Society for Endocrinology Printed in Great Britain 